\section{Pengaruh Kualitas Website dan Kemudahan Penggunaan Terhadap Keputusan Pembelian Konsumen Online Shop Eigerindostore.com}

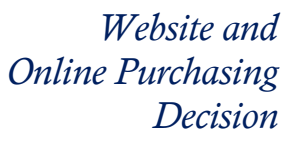

Decision

\author{
Sepriadi Solihin dan Saefudin Zuhdi \\ Program Studi Manajemen, Institut Bisnis dan Informatika Kesatuan \\ E-Mail: sepriadi.solihin@ibik.ac.id
}

13

Submitted:

SEPTEMBER 2020

Accepted: JULI 2021

\begin{abstract}
This study aims to determine and explain the influence of website quality and ease of use on purchasing decisions (eigerindostore.com online shop case study). This research was conducted on consumers of PT Eigerindo Multi Produk Industri (EMPI) who had bought products at eigerindostore.com. with a sample size of 100 respondents, the sampling technique uses the Roscoe formula. The type of research used is explanative and uses multiple linear regression analysis method using SPSS Software. The results showed that: (1) Variable website quality has a positive and significant influence on purchasing decisions. (2) The ease of use variable has a positive and significant influence on purchasing decisions. (3) website quality and ease of use together have a positive and significant influence on purchasing decisions.
\end{abstract}

Keywords: Website Quality, ease of use, and Purchasing decision.

\begin{abstract}
ABSTRAK
Penelitian ini bertujuaan untuk mengetahui dan menjelaskan Pengaruh kualitas website dan kemudahan penggunaan terhadap keputusan pembelian ( Studi kasus online shop eigerindostore.com). Penelitian ini dilakukan pada konsumen PT Eigerindo Multi Produk Industri (EMPI) yang pernah membeli produk di eigerindostore.com. dengan jumlah sampel sebanyak 100 responden, teknik sampling menggunakan rumus Roscoe. Tipe penelitian yang digunakan adalah eksplanatif dan menggunakan metode Analisis linier Regresi berganda dengan menggunakan Software SPSS. Hasil penelitian menunjukan bahwa : (1) Variable kualitas website mempunyai pengaruh positif dan signifikan terhadap keputusan pembelian. (2) Variable kemudahaan penggunaan mempunyai pengaruh positif dan signifikan terhadap keputusan pembelian. (3) kualitas website dan kemudahan penggunaan secara Bersama-sama Memiliki pengaruh yang positif dan signifikan terhadap keputusan pembelian.
\end{abstract}

Kata Kunci : Kualitas Website, Kemudahan Penggunaan, Keputusan pembelian.

\section{PENDAHULUAN}

Perkembangan teknologi internet telah mempermudah banyak hal di berbagai bidang salah satunya pada bidang ekonomi. Dalam bidang ekonomi internet menjadi salah satu media transaksi yang mempermudah pelaku ekonomi dalam menjalankan bisnis mereka sehingga faktor jarak dan waktu tidak lagi menjadi suatu permasalahan. Hal tersebut membuat banyak pelaku ekonomi mulai gencar menjadikan internet sebagai salah satu penunjang kegiatan bisnis mereka. Selain dapat menjalin hubungan bisnis dengan pelanggan secara lebih luas dan efisien, pelaku ekonomi juga dapat memangkas biayabiaya yang seharusnya dikeluarkan. Hal inilah yang disadari sebagai peluang yang baik dalam menawarkan barang dan jasa kepada para konsumen melalui internet dalam pengaksesannya. Semakin tahun pertumbuhan pengguna internet khususnya di indonesia semakin meningkat Menurut data survei pengguna internet yang diselenggarakan di 42

\section{JIKES}

Jurnal Informatika Kesatuan Vol. 1 No. 1, 2021 page. 13-22
IBI Kesatuan ISSN $x x x x-x x x x$ DOI: $10.37641 /$ jikes.v1i1.403 
Website and Online Purchasing Decision

\section{4}

kota di Indonesia oleh Asosiasi Penyelenggara Jasa Internet Indonesia (APJII) pada tahun 2017 pengguna internet di Indonesia mencapai 143,26 juta jiwa atau sekitar 54,68\% dari 262 juta orang sedangkan tahun 2018 meningkat hingga mencapai 171,17 juta jiwa atau sekitar $64,8 \%$ dari total Populasi penduduk Indonesia 264,16 juta orang.

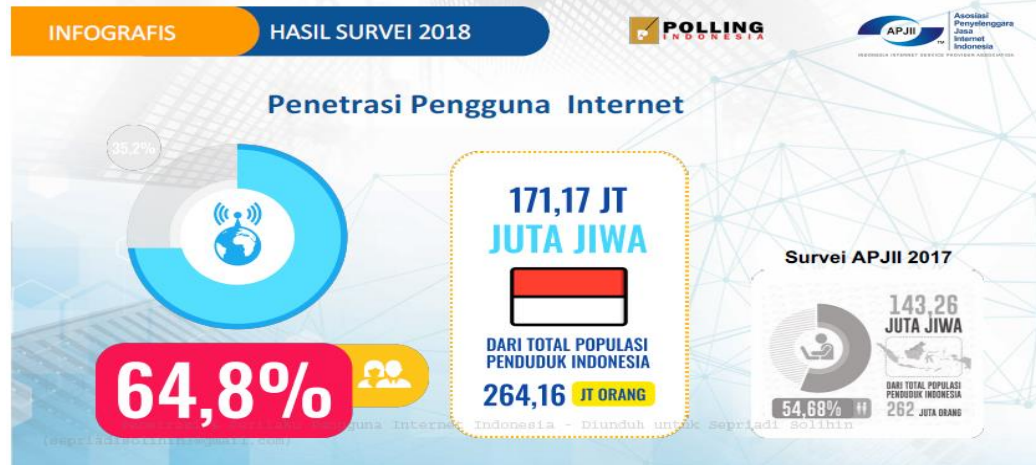

Gambar 1. Hasil survei penetrasi pengguna internet penduduk Indonesia 2018

Hal ini menjadi peluang bisnis bagi pihak-pihak yang kemudian melihat fenomena ini sebagai peluang bisnis dengan menyediakan atau membuat toko online sebagai bagian dari e-commerce. E-commerce telah menjadi bagian dari dinamika bisnis di era kemajuan teknologi informasi yang berkembang pesat. e-commerce berdampak besar pada praktik bisnis setidaknya dalam penyempurnaan direct marketing. Salah satu media e-commerce yaitu website. Sistem e-commerce harus menyediakan cara bagi konsumen, baik itu perorangan maupun bisnis untuk mengenali produk yang akan mereka beli. Faktor pendukung e-commerce salah satunya adalah website. Konsumen pada e-commerce berinteraksi dengan perusahaan menggunakan website. Pengukuran kualitas web yang dilakukan oleh konsumen akan membantu perusahaan untuk dapat melakukan pemeliharaan dan perbaikan terhadap website untuk meningkatkan pelayanan terhadap konsumennya. Pelayanan yang dilakukan perusahaan merupakan interaksi antara perusahaan dan konsumen yang dimulai dari web e-commerce tersebut. Jenis e-commerce pada penelitian ini adalah e-commerce business to customer (B2C), sebab jenis ini merupakan jenis e-commerce yang dapat dinilai langsung kualitas website perusahaan bisnis oleh konsumen akhirnya.

E-commerce atau transaksi perdagangan elektronik di Indonesia dari tahun ketahun selalu mengalami peningkatan, menurut data Marketer menunjukkan bahwa transaksi $e$ commerce Indonesia mencapai Rp 25,1 triliun pada 2014 dan akan naik menjadi Rp 69,8 triliun pada 2016, dengan kurs rupiah Rp 13.200 per dolar Amerika seiring dengan pertumbuhan pengguna internet semakin banyak juga e-commerce bermunculan dengan begitu seseorang yang membutuhkan suatu produk dapat mendapatkan yang diinginkan dari penyedia barang dengan mudah dan instan. Tujuan dari ini semua untuk meningkatkan omzet usaha. Manfaat online shopping untuk pembeli atau konsumen diantaranya sebagai berikut:

a. Manfaat online shopping bagi konsumen adalah sebagai berikut :

1. Kemudahan

Pembeli bisa memesan produk yang diinginkan tanpa terhalang waktu karena proses pemesanan bisa dilakukan kapan saja, dimana saja tanpa harus datang ke toko untuk berbelanja sehingga tidak usaha buang waktu dan tenaga untuk membeli barang yang diinginkan.

2. Informasi

Pelanggan dapat memperoleh informasi komparatif tentang perusahaan, produk, harga dan pesaing tanpa meninggalkan kantor atau rumah. Mereka dapat memusatkan perhatian pada kriteria objektif seperti harga, kualitas, kinerja, dan ketersediaan.

b. Manfaat online shopping bagi pemasar adalah sebagai berikut :

1. Efisiensi biaya 
Pemasar online mencegah biaya pengelolaan toko dan biaya sewa,asuransi dan prasarana yang menyertainya. Mereka dapat membuat katalog digital dengan biaya yang jauh lebih rendah daripada percetakan dan pengiriman katalog kertas.

2. Penyesuaian yang cepat terhadap kondisi pasar

Perusahaan dapat dengan cepat menambahkan produk pada penawaran mereka serta mengubah harga dan deskripsi produk. Artinya bagaimana seseorang yang membutuhkan suatu produk dapat mendapatkan yang diinginkan dari penyedia barang dengan mudah dan instan. Tujuan dari ini semua untuk meningkatkan omset usaha.

Pertumbuhan industri e-commerce di Tanah Air turut meningkatkan jumlah pembeli melalui platform tersebut. Salah satu portal kode diskon untuk situs-situs belanja online di Indonesia, CupoNation, memprediksi jumlah pembeli online sampai akhir tahun ini akan tumbuh signifikan. "Jumlah online shopper di Indonesia terus meningkat selama beberapa tahun terakhir. Di tahun 2018, jumlah online shopper diperkirakan mencapai 11,9 persen dari total populasi di Indonesia," demikian keterangan tertulis dari CupoNation yang diterima Kompas.com pada Jumat (7/9/2018).

Olivia Putri (Public Relations and Communications Manager CupoNation) menjelaskan dari studi internal pihaknya, didapati pertumbuhan pembeli secara online atau online shopper di Indonesia terjadi dalam tiga tahun terakhir. Pada tahun 2016, jumlah pembeli online mencapai 9,6 persen dari jumlah populasi dan meningkat menjadi 10,7 persen pada tahun 2017. Persentase tersebut didapat dengan membagi jumlah populasi dan jumlah pembeli secara online di Indonesia setiap tahunnya. Pertumbuhan jumlah pembeli online ini didukung oleh pendapatan dari pasar e-commerce Indonesia, di mana ada 6,1 miliar dollar AS pada 2016 dan mencapai 7,5 miliar dollar AS untuk tahun 2017. Tahun ini diperkirakan pendapatan pasar e-commerce bisa mencapai 9,1 miliar dollar AS. Data dalam penelitian ini bersumber dari lembaga statistik internasional bernama Statista. Data yang ditampilkan berasal dari total pendapatan bersih pasar e-commerce yang dibagi ke dalam beberapa sektor utama. (Kompas.com)

Dengan demikian adanya peningkatan online shoper khususnya di indonesia ada pergeseran kebiasaan dari belanja langsung datang ke toko-toko menjadi pembelian online melalui akses jaringan internet. Penulis melihat ada peluang yang sangat besar untuk meningkatkan penjualan melalui online shop. Online shopping adalah pembelian yang dilakukan via internet sebagai media pemasaran dengan menggunakan website sebagai katalog. Contoh dari online shopping antara lain, kalibreshop.com, nama-indonesia.com, matahari.com, dan porteegoods.com Banyaknya online shop yang menyediakan kontenkonten unik dalam website mereka yang berguna untuk mempermudah online shopper untuk berbelanja secara online tanpa harus bertatap muka langsung dengan penjual. kelebihan online shop adalah selain pembeli bisa melihat desain produk juga bisa melihat harga produk hingga bisa pembayaran secara online.

Banyak perusahaan yang menyediakan fasilitas website untuk memudahkan pembelian secara online diantaranya adalah PT Eigerindo Multi Produk Industri (EMPI) dengan website www.eigerindostore.com. Sebagai perusahaan terbesar dalam industri penyedia kebutuhan outdoor, PT Eigerindo Multi Produk Industri juga menyediakan website untuk para konsumen dalam berbelanja online dan semakin serius membidik penjualan dari channel online. Produsen tas bermerek Eiger, Export dan BodyPack, ini menargetkan pada tahun 2020 penjualan online bisa berkontribusi 8 - 10\%. Tetapi Andreant (Head of Ecommerce Eiger Indonesia) menyatakan untuk saat ini kontribusi dari belanja online masih kecil dibawah $2 \%$ dari total sales.

Sejak satu setengah tahun lalu, kata dia, perusahaan mulai serius menggarap pasar online lewat channel-channel jual beli online. Saat ini selain menggarap online store sendiri, Eiger juga bekerja sama dengan 6 situs jual beli online, bahkan juga bekerja sama dengan sebuah e-commerce enabler. Hari Belanja Online Nasional yang jatuh pada 11 November lalu atau pesta diskon 11.11, ia mencontohkan tas Dalam Peringatan Hari Belanja Online Eiger berhasil mencatatkan angka penjualan sebesar 2.200 transaksi selama empat hari.
Website and

Online Purchasing

Decision 
Website and Online Purchasing Interest
Berdasarkan dari uraian latar belakang diatas maka dapat diidentifikasikan masalah seperti berikut:

1. eigerindostore.com belum bisa berkontribusi besar dari online shop masih kecil dibawah $2 \%$ dari total sales PT Eigerindo Multi Produk Industri.

2. content website eigerindostore.com sangat beragam navigasi.

3. Kebutuhan masyarakat akan kemudahan penggunaan pada saat online shopping.

Berdasarkan latar belakang dan identifikasi masalah yang dituturkan di atas maka tujuan penelitian ini adalah sebagai berikut (1) Untuk mengetahui pengaruh kualitas website terhadap keputusan online shopping di eigerstore.com. (2) Untuk mengetahui pengaruh kemudahan penggunaan terhadap keputusan online shopping di eigerindostore.com. (3) Untuk mengetahui pengaruh kualitas website, dan kemudahan penggunaan berpengaruh terhadap keputusan pembelian di eigerindostore.com

\section{Paradigma Penelitian}

Berdasarkan kerangka pemikiran yang mengacu pada faktor-faktor yang memiliki pengaruh terhadap keputusan pembelian diatas maka dapat digambarkan paradigma penelitian sebagai berikut ini :

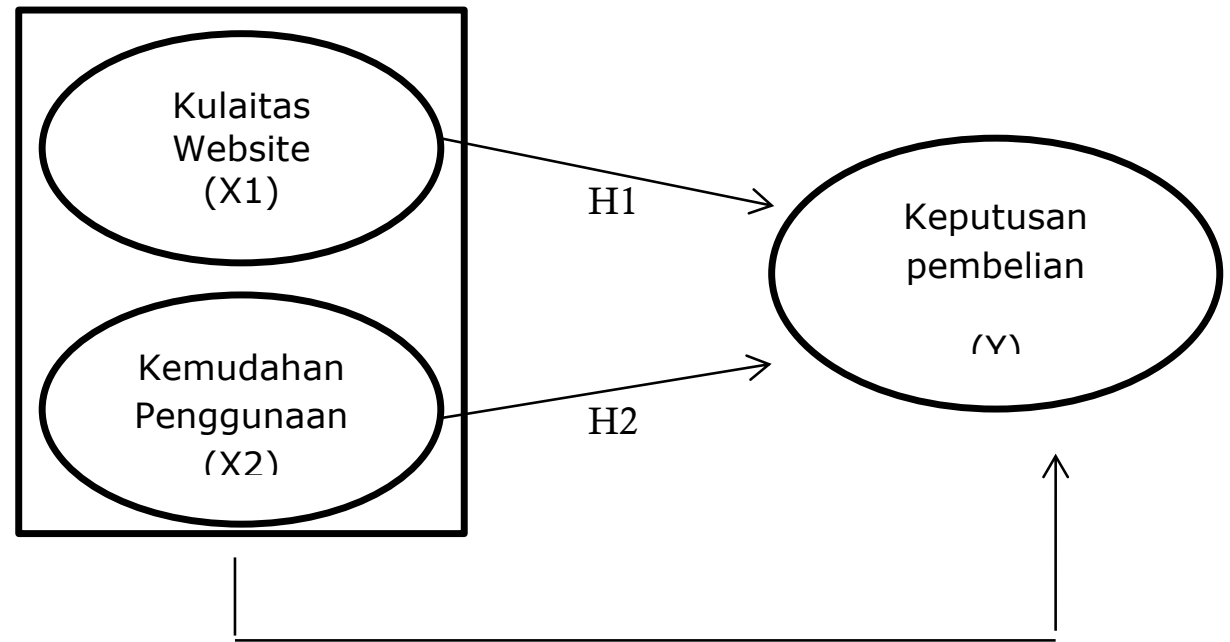

H3

\section{Gambar 2. Pradigma Penelitian}

Dimana: X1 : Kualitas website; X2 : Kemudahan Penggunaan; Y : Keputusan Pembelian $\mathrm{H} 1$ : Pengaruh X1 terhadap Y; H2 : Pengaruh X2 terhadap Y

$\mathrm{H} 3$ : Pengaruh $\mathrm{X} 1$, dan $\mathrm{X} 2$, secara simultan terhadap $\mathrm{Y}$

\section{METODE PENELITIAN}

Lokasi penelitian ini dilakukan pada konsumen PT Eigerindo Multi Produk Industri yang pernah belanja online di eigerindostore.com. Data yang diperoleh dari penelitian yang dilakukan oleh penulis terdiri dari dua jenis data, yaitu: (a) Data Kualitatif; Dimana data yang diperoleh berbentuk kata, kalimat, skema dan gambar seperti teori-teori dan literature, yang termasuk data kualitatif dalam penelitian ini yaitu gambaran umum objek penelitian, meliputi : Sejarah singkat berdirinya, Visi dan Misi, kualitas web, kemudahan penggunaan, dan Keputusan Pembelian. (b) Data Kuantitatif; adalah jenis data yang dapat diukur atau dihitung secara langsung, yang berupa informasi atau penjelasan yang dinyatakan dalam bilangan atau berbentuk angka-angka. Dalam penelitian ini data kuantitatif adalah konsumen PT Eigerindo Multi Produk Industri.

Data primer penelitian ini terdiri dari : Data karakteristik responden berdasarkan jenis kelamin, Data karakteristik responden berdasarkan Usia, Data karakteristik responden berdasarkan Pendidikan, Data karakteristik responden berdasarkan pekerjaan, Data karakteristik responden berdasarkan penghasilan, Data persepsi responden tentang variable Kualitas website, Data persepsi responden tentang variable kemudahan 
penggunaan dan Data persepsi responden tentang variable keputusan pembelian. Sedangkan Data sekunder penelitian ini terdiri atas: Data teori tentang variable Kualitas website, Data teori tentang variable kemudahan penggunaan, Data teori tentang variable keputusan pembelian dan Data penelitian terdahulu. Populasi yang digunakan dalam penelitian ini adalah konsumen yang membeli produk PT Eigerindo Multi Produk Industri melalui eigerindostore.com. Data dari sampel penelitian dianalisis dengan uji validitas, uji reliabilitas, uji asumsi klasik, uji korelasi dan regresi berganda.

\section{HASIL DAN PEMBAHASAN \\ Karakteristik Responden}

Penelitian ini adalah Pengaruh Kualitas Website dan Kemudahan penggunaan Terhadap Keputusan Pembelian (Studi kasus online shop eigerindostore.com). berdasarkan pernyataan Roscoe banyaknya responden harus disesuaikan dengan banyaknya indikator yang digunakan pada penelitian ini adalah :

Rumus $=\sum$ Indikator $x 10=10$ Indikator $\mathrm{x} 10=100$ Responden .

Berdasarkan hasil perhitungan tersebut, peneliti memutuskan untuk menetapkan jumlah responden sebanyak 100 orang sebagai sampel penelitianyang mewakili populasi

Tabel 1. Sebaran Responden Berdasarkan Karakteristik

\begin{tabular}{|c|c|c|c|c|c|}
\hline \multicolumn{2}{|c|}{ Karakteristik } & Frequency & Percent & $\begin{array}{c}\text { Valid } \\
\text { Percent }\end{array}$ & $\begin{array}{c}\text { Cumulative } \\
\text { Percent }\end{array}$ \\
\hline \multirow{3}{*}{$\begin{array}{l}\text { Jenis } \\
\text { Kelamin }\end{array}$} & Laki-laki & 63 & 63.0 & 63.0 & 63.0 \\
\hline & Perempuan & 37 & 37.0 & 37.0 & 100.0 \\
\hline & Total & 100 & 100.0 & 100.0 & \\
\hline \multirow[t]{4}{*}{ Usia } & $<20$ Tahun & 12 & 12.0 & 12.0 & 12.0 \\
\hline & $21-25$ Tahun & 67 & 67.0 & 67.0 & 79.0 \\
\hline & $>25$ Tahun & 21 & 21.0 & 21.0 & 100.0 \\
\hline & Total & 100 & 100.0 & 100.0 & \\
\hline \multirow{6}{*}{$\begin{array}{l}\text { Tingkat } \\
\text { Pendidikan }\end{array}$} & SMA/SMK & 31 & 31.0 & 31.0 & 31.0 \\
\hline & Diploma & 8 & 8.0 & 8.0 & 39.0 \\
\hline & Sarjana & 58 & 58.0 & 58.0 & 97.0 \\
\hline & Pasca sarjana & 1 & 1.0 & 1.0 & 98.0 \\
\hline & Lainnya & 2 & 2.0 & 2.0 & 100.0 \\
\hline & Total & 100 & 100.0 & 100.0 & \\
\hline \multirow[t]{6}{*}{ Pekerjaan } & Pelajar/Mahasiswa & 43 & 43.0 & 43.0 & 43.0 \\
\hline & Wirausaha & 14 & 14.0 & 14.0 & 57.0 \\
\hline & Pegawai Swasta & 33 & 33.0 & 33.0 & 90.0 \\
\hline & Pegawain Negeri & 2 & 2.0 & 2.0 & 92.0 \\
\hline & Lainnya & 8 & 8.0 & 8.0 & 100.0 \\
\hline & Total & 100 & 100.0 & 100.0 & \\
\hline \multirow{4}{*}{$\begin{array}{l}\text { Tingkat } \\
\text { Penghasilan }\end{array}$} & $<2 \mathrm{Jt}$ & 39 & 39.0 & 39.0 & 39.0 \\
\hline & $2-5 \mathrm{Jt}$ & 45 & 45.0 & 45.0 & 84.0 \\
\hline & $>5 \mathrm{Jt}$ & 16 & 16.0 & 16.0 & 100.0 \\
\hline & Total & 100 & 100.0 & 100.0 & \\
\hline
\end{tabular}

Sumber: Data Primer Diolah, 2020

Tabel 1. menunjukan bahwa mayoritas responden yang sering belanja online di eigerindostore.com itu adalah laki-laki, mayoritas responden yang sering belanja online di eigerindostore.com yaitu berusia $21-25$ tahun, mayoritas responden yang sering belanja online di eigerindostore.com berdasarkan karakteristik Pendidikan terakhir yaitu Sarjana, mayoritas responden yang sering belanja online di eigerindostore.com berdasarkan karakteristik Pekerjaan yaitu Pelajar/Mahasiswa, mayoritas responden yang sering belanja online di eigerindostore.com berdasarkan karakteristik Penghasilan perbulan yaitu yang perbenghsilan 2.000.000 - 5.000.000.

\section{Persepsi Responden}

Untuk mengetahui indeks jawaban responden maka dibuatlah distribusi jawaban sebagaimana pada Tabel 3. Skala yang digunakan dalam responden tersebut adalah $5,4,3,2,1$ maka range dari skala tersebut adalah 5-1=4. Kemudian dibagi ke dalam 5
Website and

Online Purchasing

Decision 
Website and Online Purchasing Interest kategori yang meliputi sangat tidak setuju, tidak setuju, ragu-ragu, setuju dan sangat setuju. Maka dapat interval $\frac{4}{5}=0,8$ dan distribusi sebagai berikut:

Tabel 2. Kelas dan kategori indeks jawaban responden

\begin{tabular}{|c|c|c|}
\hline No & Interval & Kategori \\
\hline 1 & $1,00-1,80$ & Sangat Rendah \\
\hline 2 & $1,81-2,61$ & Rendah \\
\hline 3 & $2,62-3,42$ & Sedang \\
\hline 4 & $3,43-4,23$ & Tinggi \\
\hline 5 & $4,24-5,00$ & Sangat Tinggi \\
\hline
\end{tabular}

( Sumber : Sugiyono 2008)

Tabel 3. Tabel Indeks Jawaban Responden Indikator Variabel Penelitian

\begin{tabular}{|c|c|c|c|c|c|c|c|c|}
\hline \multirow{2}{*}{ No } & \multirow{2}{*}{ Pernyataan } & \multicolumn{5}{|c|}{ Skala } & \multirow{2}{*}{$\begin{array}{l}\text { Rata- } \\
\text { rata }\end{array}$} & \multirow{2}{*}{ Kategori } \\
\hline & & 5 & 4 & 3 & 2 & 1 & & \\
\hline \multicolumn{9}{|c|}{ KUALITAS WEBSITE } \\
\hline 1 & $\begin{array}{l}\text { Website eigerindostore.com } \\
\text { memiliki daya tarik gambar produk } \\
\text { menarik. }\end{array}$ & 41 & 50 & 8 & 1 & 0 & 4,31 & Sangat Tinggi \\
\hline 2 & $\begin{array}{l}\text { Website eigerindostore.com } \\
\text { Tampilan desain \& warna yang } \\
\text { disajikan serasi. }\end{array}$ & 29 & 60 & 9 & 2 & 0 & 4,07 & Tinggi \\
\hline 3 & $\begin{array}{l}\text { Pengoprasian website } \\
\text { eigerindostore.com mudah di } \\
\text { pelajari. }\end{array}$ & 18 & 63 & 15 & 4 & 0 & 3,95 & Tinggi \\
\hline 4 & $\begin{array}{l}\text { Website menyediakan fiture search } \\
\text { memudahkan memcari produk. }\end{array}$ & 42 & 49 & 7 & 1 & 1 & 4,3 & Sangat Tinggi \\
\hline 5 & $\begin{array}{l}\text { Informasi yang di sajikan website } \\
\text { eigerindostore.com detail. }\end{array}$ & 22 & 55 & 17 & 6 & 0 & 3,93 & Tinggi \\
\hline 6 & $\begin{array}{l}\text { Informasi yang di sajikan website } \\
\text { eigerindostore.com dapat dipercaya. }\end{array}$ & 32 & 57 & 8 & 2 & 1 & 4,17 & Tinggi \\
\hline 7 & $\begin{array}{l}\text { eigerindostore.com memberikan } \\
\text { rasa aman terhadap informasi } \\
\text { peribadi pengguna. }\end{array}$ & 19 & 56 & 25 & 0 & 0 & 3,94 & Tinggi \\
\hline 8 & $\begin{array}{l}\text { eigerindostore.com memberi ruang } \\
\text { untuk berkomunikasi via livechat. }\end{array}$ & 32 & 40 & 18 & 10 & 0 & 3,94 & Tinggi \\
\hline \multicolumn{9}{|c|}{ KEMUDAHAN PENGGUNAAN } \\
\hline 1 & $\begin{array}{l}\text { Fiture search Website } \\
\text { eigerindostore.com memudahkan } \\
\text { mencari produk. }\end{array}$ & 45 & 47 & 6 & 2 & 0 & 4,35 & Sangat Tinggi \\
\hline 2 & $\begin{array}{l}\text { Interaksi dengan website } \\
\text { eigerindostore.com jelas dan mudah } \\
\text { dipahami. }\end{array}$ & 26 & 56 & 15 & 2 & 1 & 4,04 & Tinggi \\
\hline 3 & $\begin{array}{l}\text { website eigerindostore.com } \\
\text { Memberi ruang berkomunikasi } \\
\text { dengan live chat. }\end{array}$ & 25 & 48 & 25 & 2 & 0 & 3,96 & Tinggi \\
\hline \multicolumn{9}{|c|}{ KEPUTUSAN PEMBELIAN } \\
\hline 1 & $\begin{array}{l}\text { Belanja di eigerindostore.com } \\
\text { memiliki daya Tarik gambar produk } \\
\text { yang menarik. }\end{array}$ & 44 & 50 & 5 & 1 & 0 & 4,37 & Sangat Tinggi \\
\hline 2 & $\begin{array}{l}\text { Belanja di eigerindostore.com } \\
\text { Efisien waktu dalam melakukan } \\
\text { pembelian. }\end{array}$ & 42 & 49 & 8 & 1 & 0 & 4,32 & Sangat Tinggi \\
\hline 3 & $\begin{array}{l}\text { Membeli produk di website } \\
\text { eigerindostore.com informasi } \\
\text { produk detail dan terpercaya. }\end{array}$ & 29 & 56 & 13 & 2 & 0 & 4,12 & Tinggi \\
\hline
\end{tabular}

\section{Sumber: Data Primer Diolah}

Dari tabel perhitungan indeks responden untuk indikator variable Kualitas website, diperoleh nilai tertinggi sebesar 4,31 pada pernyataan 1 hal ini karena, Website 
eigerindostore.com memiliki daya tarik gambar produk menarik. Sedangkan nilai terendah sebesar 3,93 pada pernyataan 5 Informasi yang di sajikan website eigerindostore.com detail. Untuk indikator variable kemudahaan penggunaan, diperoleh nilai tertinggi sebesar 4,35 pada pernyataan 1 hal ini karena, Fiture search Website eigerindostore.com memudahkan mencari produk. Sedangkan nilai terendah sebesar 3,96 pada pernyataan 3 website eigerindostore.com Memberi ruang berkomunikasi dengan live chat.detail. Untuk indikator variable keputusan pembelin, diperoleh nilai tertinggi sebesar 4,37 pada pernyataan 1 hal ini karena, Belanja di eigerindostore.com memiliki daya Tarik gambar produk yang menarik. Sedangkan nilai terendah sebesar 4,12 pada pernyataan Membeli produk di website eigerindostore.com informasi produk detail dan terpercaya.

\section{Uji Kualitas Data}

Berdasarkan Hasil Uji Validitas terhadap Variabel X1 (Kualitas Website) menyatakan bahawa hasil r-product hitung pernyataan ke 1 yaitu 0,602 pernyataan ke 2 Yaitu 0,859 pernyataan ke 3 yaitu 0,812 Untuk pernyataan ke 4 Yaitu 0,587 untuk penyataan ke 5 yaitu 0,737 untuk Pernyataan ke 6 yaitu 0,660 untuk pernyataan ke 7 0,473 dan untuk pernyataan ke 8 yaitu 0,783. Untuk Variabel X2 (Kemudahan Penggunaan), nilai rproduct pernyataan ke 1 yaitu 0,759 pernyataan ke 2 Yaitu 0,860 dan pernyataan ke 3 yaitu 0,882 . Hasil r-product moment hitung di atas menunjukan hasil lebih besar dari $r$ product. Untuk Variable Y (Keputusan Pembelian) nilai r-product moment pernyataan ke 1 Yaitu 0,798 pernyataan ke 2 Yaitu 0,775 dan pernyataan ke 3 Yaitu 0,785. Hasil rproduct moment hitung di atas menunjukan hasil lbih besar dari r product. moment tabel, $\mathrm{n}=30, \alpha=5 \%$ yaitu 0.361 dan nilai signifikansi dibawah $5 \%$ sehingga kesimpulannya adalah valid dan dapat digunakan untuk penelitian selanjutnya. Berdasarkan uji reliabilitas diperoleh hasil Cronbach's Alpha untuk variable kualitas website sebesar 0,798 , untuk variable kemudahan penggunaan sebesar 0,684 , untuk variable keputusan pembelian sebesar 0,785 dan nilai Cronbach's Alpha lebih kecil 0,6 Maka data dinyatakan reliabel.

Hasil nilai uji normalitas diketahui bahwa nilai signifikan sebesar 0,126 lebih besar dari pada 0,0 sehingga dapat disimpulkan bahwa data yang diuji berdistribusi normal. Berdasarkan Uji Multikolinearitas variabel kualitas website (X1) diperoleh nilai tolerance sebesar 0,460 dan nilai VIF sebesar 2,173; variabel kemudahan pengunaan (X2) diperoleh nilai tolerance sebesar 0,460 dan nilai VIF 2,173 Variabel X1 dan X2 memperoleh nilai VIF dibawah 10 maka Hasil tersebut dapat disimpulkan bahwa seluruh variabel independen penelitian ini tidak ada gejala multikolinearitas. Hasil uji heteroskedastisitas diperoleh bahwa variabel X1 (kualitas website)mempunyai nilai signifikansi sebesar 0,007 lebih kecil dari 0,05 Atau dibawah 5\%. Variabel X2 (kemudahan penggunaan) mempunyai nilai signifikansi sebesar 0,0,14 lebih kecil dari 0,05 atau dibawah $5 \%$ dengan demikian dapat disimpulkan bahwa terjadi Heterokedastitas atau tidak bersifat homoskedastisitas.

\section{Kolerasi Antar Variabel}

Analisis Kolerasi digunakan untuk melihat adanya hubungan antar variabel Kualitas Website, Kemudian Penggunaan dan Keputusan Pembelian serta keeratan hubungannya maka dari itu dilakukan analisis korelasi. Hasil analisis dari korelasi adalah koefisien kolerasi yang menunjukan kekuatan dan kelemahan dari suatu hubungan. Sedangkan untuk membuktikan ada tidaknya pengaruh antar variabel, akan dilakukan analisis regresi simultan untuk masing-masing variabel pada masing-masing variabel.

Tabel 4. Kolerasi Antar Variabel

\begin{tabular}{|l|l|c|c|}
\hline \multicolumn{2}{|l|}{} & Kualitas Website & Kemudahan Penggunaan \\
\hline \multirow{3}{*}{ Keputusan Pembelian } & Pearson Correlation & $.757^{* *}$ & $.666^{* *}$ \\
\cline { 2 - 4 } & Sig. (2-tailed) & .000 & .000 \\
\cline { 2 - 4 } & $N$ & 100 & 100 \\
\hline
\end{tabular}

Sumber: Data Output SPPS diolah (2020)

Berdasarkan Tabel 4 :

Website and

Online Purchasing

Decision 
Website and Online Purchasing Interest
1. menunjukan bahwa variabel Kualitas website, berkorelasi positif sebesar 0,735 terhadap kemudahan penggunaan dan dapat disimpulkan kedua variabel tersebut terdapat korelasi yang signifikan antara variabel yang dihubungkan, memiliki hubungan yang kuat.

2. menunjukan bahwa variabel kualitas website berkolerasi positif sebesar 0,757 terhadap keputusan pembelian dan dapat disimpulkan kedua variabel tersebut kolerasi yang signifikan antar variabel yang dihubungkan, memiliki hubungan yang kuat.

3. menujukan bahwa variabel kemudahaan penggunaan berkolerasi positif sebesar 0,735 terhadap kualitas website dan dapat disimpulkan kedua variabel tersebut terdapat yang signifikan antar variabel yang dihubungkan memiliki hubungan yang kuat

Analisis Regresi Berganda

Hasil analisis mengenai koefisien model regresi seperti tercantum dalam tabel 5.

Tabel 5. Pembentukan persamaan regresi

\begin{tabular}{|c|c|c|c|c|c|}
\hline \multirow[t]{2}{*}{ Model } & \multicolumn{2}{|c|}{$\begin{array}{l}\text { Unstandardized } \\
\text { Coefficients }\end{array}$} & $\begin{array}{c}\text { Standardized } \\
\text { Coefficients }\end{array}$ & \multirow[t]{2}{*}{$\mathrm{t}$} & \multirow[t]{2}{*}{ Sig. } \\
\hline & $\mathrm{B}$ & Std. Error & Beta & & \\
\hline (Constant) & 2.413 & .872 & & 2.768 & .007 \\
\hline 1 Kualitas Website & .238 & .039 & .582 & 6.143 & .000 \\
\hline Kemudahaan penggunaan & .212 & .084 & .238 & 2.514 & .014 \\
\hline
\end{tabular}

a. Dependent Variable: Keputusan pembelian

Sumber: Data Output SPPS diolah (2020)

Berdasarkan tabel 21 dapat ditemukan persamaan regresi berganda untuk penelitian ini sebagai berikut :

$\mathrm{Y}=2.413+0,238+0,212+$ error

Berdasarkan persamaan regresi di atas, jika :

a. Kualitas website $=$ kemudahan penggunaan $=0$, maka nilai dari keputusan pembelian online di eigerindostore.com nilainya sebesar 2,413

b. Jika kualitas website sebesar 1 (satu) satuan maka keputusan pembelian online di eigerindostore.com nilainya sebesar 0,238 Jika variabel lain dianggap konstan.

c. Jika kemudahan penggunaan naik sebesar 1 (satu) satuan maka keputusan pembelian online di eigerindostore.com nilainya sebesar 0,212 Jika variable lain dianggap konstan.

\section{Koefisien Determinasi}

Hasil analisis koefisien determinan adalah sebagai berikut:

Tabel 6. Koefisien Korelasi dan Determinasi

\begin{tabular}{|c|c|c|c|c|c|c|c|c|c|}
\hline \multirow[b]{2}{*}{ Model } & \multirow[b]{2}{*}{$\mathrm{R}$} & \multirow[b]{2}{*}{$\begin{array}{c}\mathrm{R} \\
\text { Square }\end{array}$} & \multirow[b]{2}{*}{$\begin{array}{l}\text { Adjusted } \\
\text { R Square }\end{array}$} & \multirow{2}{*}{$\begin{array}{l}\text { Std. Error } \\
\text { of the } \\
\text { Estimate }\end{array}$} & \multicolumn{5}{|c|}{ Change Statistics } \\
\hline & & & & & $\begin{array}{c}\text { R Square } \\
\text { Change }\end{array}$ & $\begin{array}{c}\mathrm{F} \\
\text { Change }\end{array}$ & df1 & $\mathrm{df} 2$ & $\begin{array}{c}\text { Sig. F } \\
\text { Change }\end{array}$ \\
\hline 1 & $.774^{\mathrm{a}}$ & 599 & .591 & .982 & .599 & 72.534 & 2 & 97 & .000 \\
\hline
\end{tabular}

Sumber: Data Output SPPS diolah (2020)

Berdasarkan pada tabel 6 . hasil output modal summary dapat dijelaskan bahwa hubungan atau kolerasi berganda pada seluruh variable (kualitas website, kemudahan penggunaan dan Keputusan Pembelian di eigerindostore.com). Memiliki kekuatan hubungan yang kuat. Hal ini karena dilihat berdasarkan nilai koefisien korelasi berganda sebesar 0,774 Perolehan nilai koefisien determinasi R-Square sebesar 0,599. Dapat dijelaskan bahwa variabel kualitas website dan kemudahan penggunaan secara bersamasama mampu menjelaskan keragaman (variabilitas) dari keputusan pembelian sebesar $55,9 \%$ Sedangkan sisanya sebesar $(100 \%-55,9 \%=44,1 \%)$ dipengaruhi di luar faktor lain atau dijelaskan oleh variabel lain yang tidak teliti.

\section{Uji Hipotesis Statistik}

Hipotesis pengujian antara kualitas website terhadap keputusan pembelian secara parsial. 


\begin{tabular}{|l|l|}
\hline $\mathrm{H} 0: ß=0$ & $\begin{array}{l}\text { Tidak terdapat pengaruh antara Kualitas website terhadap } \\
\text { Keputusan pembelian. }\end{array}$ \\
\hline $\mathrm{H} 1: ß \neq 0$ & $\begin{array}{l}\text { terdapat pengaruh antara Kualitas website terhadap Keputusan } \\
\text { pembelian. }\end{array}$ \\
\hline
\end{tabular}

Berdasarkan tabel 5. pengaruh Kualitas website (X1) terhadap keputusan pembelian di eigerindostore.com $(\mathrm{Y})$ diperoleh $\mathrm{t}$ hitung sebesar 6,143 dan lebih besar dari t-tabel $(\mathrm{df}=\mathrm{n}$ $\mathrm{k}-1$ atau $\mathrm{df}=100-2-1=97 ; \alpha=5 \%)=1,66$ dan nilai signifikan $0,000<0,05 ; \mathrm{H} 0$ ditolak H1 diterima. Kesimpulan hipotesis penelitian pertama diterima, artinya ada pengaruh yang positif dan signifikan antara kualitas website (X1) terhadap keputusan pembelian online di eigerindostore.com (Y).

Hipotesis pengujian antara Kemudahan penggunaan terhadap keputusan pembelian secara parsial.

\begin{tabular}{|l|l|}
\hline $\mathrm{H} 0: \beta=0$ & $\begin{array}{l}\text { Tidak terdapat pengaruh antara kemudahaan penggunaan } \\
\text { terhadap Keputusan pembelian. }\end{array}$ \\
\hline $\mathrm{H} 1: ß \neq 0$ & $\begin{array}{l}\text { terdapat pengaruh antara kemudahan penggunaan terhadap } \\
\text { Keputusan pembelian. }\end{array}$ \\
\hline
\end{tabular}

Berdasarkan tabel 5, pengaruh kemudahan penggunaan (X2) terhadap keputusan pembelian di eigerindostore.com (Y) diperoleh t hitung sebesar 2,514 dan lebih besar dari $\mathrm{t}$-tabel $(\mathrm{df}=\mathrm{n}-\mathrm{k}-1$ atau $\mathrm{df}=100-2-1=97 ; \alpha=5 \%)=1,66$ dan nilai signifikan $0,000<0,05 ; \mathrm{H} 0$ ditolak H1 diterima. Kesimpulan hipotesis penelitian pertama diterima, artinya ada pengaruh yang positif dan signifikan antara kemudahaan penggunaan (X2) terhadap keputusan pembelian online di eigerindostore.com $(\mathrm{Y})$.

Hasil analisis mengenai uji $\mathrm{F}$ atau ANOVA tercantum pada tabel berikut:

Tabel 7. Uji Simultan ( Uji F )

\begin{tabular}{|l|l|r|r|r|r|c|}
\hline \multicolumn{2}{|l|}{ Model } & Sum of Squares & \multicolumn{1}{c|}{ df } & Mean Square & F & Sig. \\
\hline \multirow{3}{*}{1} & Regression & 139.867 & 2 & 69.934 & 72.534 & $.000^{\mathrm{b}}$ \\
\cline { 2 - 8 } & Residual & 93.523 & 97 & .964 & & \\
\cline { 2 - 7 } & Total & 233.390 & 99 & & & \\
\hline
\end{tabular}

Sumber: Data Output SPPS diolah (2020)

Hipotesis pengujian antara Kualitas website dan kemudahan penggunaan terhadap keputusan pembelian secara simultan.

\begin{tabular}{|l|l|}
\hline $\mathrm{H} 0: \beta_{1}=\beta_{2}=\beta_{3}=0$ & $\begin{array}{l}\text { tidak terdapat pengaruh antara Kualitas website , } \\
\text { Kemudahaan penggunaan terhadap Keputusan pembelian. }\end{array}$ \\
\hline $\mathrm{H} 1: \beta_{1} \neq \beta_{2} \neq \beta_{3} \neq 0$, & $\begin{array}{l}\text { terdapat pengaruh antara Kualitas website, Kemudahaan } \\
\text { penggunaan terhadap Keputusan pembelian. }\end{array}$ \\
\hline
\end{tabular}

Berdasarkan tabel 7. pengujian antara Kualitas website dan kemudahan penggunaan terhadap keputusan pembelian diperoleh f-hitung 72,534 dan lebih besar dari f-tabel $(\mathrm{df} 1=2, \mathrm{df} 2=97, \alpha=5 \%)=3,09$; dan didukung oleh nilai signifikansi sebesar 0,000 dan lebih kecil dari $(\alpha=5 \%)=0,05$ dengan demikian H0 ditolak dan H1 diterima Kualitas website dan kemudahan penggunaan secara simultan terhadap Keputusan Pembelian, maka hipotesis 3 diterima.

\section{PENUTUP}

Setelah hasil dan pembahasan dipaparkan, berikut ini beberapa simpulan penelitian ini:Kualitas website terhadap keputusan pembelian dapat diterima ditunjukan dengan nilai t-hitung sebesar 6,143 dimana t-hitung lebih besar dibandingkan t-tabel 1,66 dan didukung oleh signifikansi 0,000 Lebih kecil dibandingkan 0,05 mempunyai pengaruh positif dan signifikan terhadap keputusan pembelian, dilihat dari persamaan regresi.. Kemudahaan penggunaan terhadap keputusan pembelian dapat diterima ditunjukan dengan nilai t-hitung sebesar 2,,514 dimana t-hitung lebih besar dibandingkan t-tabel 1,66 dan didukung oleh signifikansi 0,014 Lebih kecil dibandingkan 0,05 mempunyai pengaruh positif dan signifikan terhadap keputusan pembelian, dilihat dari persamaan regresi. Kualitas website dan kemudahan penggunaan secara Bersama-sama Memiliki 
Website and Online Purchasing Interest

pengaruh yang positif dan signifikan terhadap keputusan pembelian, berdasarkan uji statistik yang dilakukan ditemukan bahwa kedua variabel independen tersebut mampu mempengaruhi keputusan pembelian di eigerindostore.com , diketahui berdasarkan bahwa nilai $\mathrm{F}$ hitung dari keseluruhan variabel sebesar 72,534 Sedangkan F tabelnya sebesar 2,70 yang artinya F hitung lebih besar dari F tabel sehingga H0 Ditolak dan H3 diterima. Sehingga dapat disimpulkan bahwa kualitas website dan kemudahan penggunaan. Berpengaruh secara langsung terhadap variabel Keputusan Pembelian dan signifikan.

\section{DAFTAR PUSTAKA}

[1] Ghozali, Imam. (2009). Aplikasi Analisis Multivariate dengan Program SPSS. Semarang: UNDIP.

[2] Kotler, Philip. Keller, K Lane. (2009). Manajemen Pemasaran. Edisi 13. Jilid 1 dan 2. Jakarta: Penerbit Erlangga.

[3] Sugiyono. (2014). Metode Penelitian Pendidikan Pendekatan Kuantitatif, Kualitatif, dan $R \& D$. Bandung: Alfabeta.

[4] Turban, Efraim, David king dan Judy Lang. (2011). Introduction to Electronic Commerce.Edition 3. New Jersey, Amerika Serikat: Prentice Hall.

[5] Ahn, Tony., Seewon, Ryu., dan Ingoo, Han. (2007). The impact of web quality and playfulness on user acceptance of online retailing. Journal Technology Acceptance Model.

[6] Ali Zaki dan Smithdev Community. 2008. Belajar Komputer PHP dan MySQL. Semarang: Elex Media komputindo.

[7] Almahamid, S. (2005). The Relationship Between Perceived Usefulness, Perceived Ease of Use, Perceived Information Quality, and Intention to Use E-Government. Journal of Theoretical and Applied Information Technology, 11(1), 30- 44.

[8] Booth, Alison L. and Patrick J. Nolen. 2009. Gender Differences in Risk Behaviour: Does Nurture Matter?. Institute for the Study of Labor (IZA) Discussion Paper No.4026.

[9] Coviello, N., Milley, R. and Marcolin, B. (2001). Understanding IT-enabled interactivity in contemporary marketing. Journal of Interactive Marketing, (Vol.15 No. 4, pp. 18-33).

[10] Deavaj, Fan, \& Kohli. (2003). E-Loyality Elusive Ideal or Competitive Edge Communication of the ACM.46 (9), 184-191.

[11] E. Turban, R. Sharda dan D. Delen, Decision Support and Business Intelligence Systems, 2011: Pearsson, New Jersey.

[12] Ernawati, Dewi. "Pengaruh Profitabilitas, Leverage Dan Ukuran Perusahaan Terhadap Nilai Perusahaan." Jurnal Ilmu dan Riset Akuntansi 4.4 (2016).

[13] Liu, C. K. \& Arnett, P., 2000. Exploring the factors associated with web site success in the context of electronic commerce. Information and Management, pp. 22- 22.

[14] Luis Olsina, e. a. (2006). Web Quality. Springer , 10.1007/3-540-28218-1_4, 109142.

[15] Mahir Pradana, Syafira Nanditha Danisa, 2016, Pengaruh Kualitas Website Terhadap Proses Keputusan Pembelian Pada Konsumen Flashy Shop. Jurnal Manajemen Bisnis Indonesia Vol. 3, Nomor 2, Feb 2016.

[16] Mulyana, M., 2012. Consumer Behaviour: Sukses Dengan Memahami Konsumen.

[17] Pullinger, D., and A. Bailin. 2010. Reporting on progress: Central government websites 2009/10. Central Office of Information, London.

[18] Radyan Tyas Stanza. 2018." Pengaruh kemudahan transaksi, kepercayaan konsumen dan pengalaman berbelanja terhadap minat beli ulang di situs jual beli online tokopedia".STIE Kesatuan, Bogor.

[19] Roscoe, J. T. (1975). Fundamental research statistics for the behavioural sciences. (2nd ed.) New York: Holt Rinehart \& Winston

[20] Nurachmad, E. and Sukamto, A., 2020. Pelatihan Persiapan Studi Lanjut Di Jurusan Teknologi Informasi. Jurnal Abdimas, 4(1), pp.61-70. 